\title{
PROTOTYPING A SYSTEM OF AN EARLY BUILDING DAMAGE ASSESSMENT EFFECTED BY AN EARTHQUAKE
}

\author{
Wahyu Ramadhan ${ }^{1}$, Jamaludin ${ }^{2}$ \\ Bumi Gora University ${ }^{1}$ \\ Hamzanwadi University ${ }^{2}$ \\ wahyurama24@gmail.com, jamal.ict@hamzanwadi.ac.id
}

\begin{abstract}
The main purpose of this research is to identify a level of a building damage caused by an earthquake early and in detail by utilizing an information system. Early identification of the building damage will be categorized based on three categories, namely minor damage, moderate damage and major damage. Each classification has standards and calculations set up by the government. To find out the damage categories, a current study was carried out on how to develop an information system that could be used by evaluators in determining conclusions according to observation results. Related to the research and development method, and adapting the Analysis, Design, Development, Implementation and Evaluation (ADDIE) development model, researchers collaborate between the ADDIE model and the standard building damage values decided by the government in a real time. The design of the early damage assessment tool for buildings is still under development and is still a prototype system.
\end{abstract}

Keywords: Buliding Damage, Information System, ADDIE

\section{Introduction}

Indonesia as one of the countries with very high frequency of earthquakes requires the officers in all levels to mitigate disasters. Based on data from the Meteorology Climatology and Geophysics Agency (BMKG), the average number of earthquakes each month in Indonesia is 400 times. Even in the period 1991 to 2007, there were 24 major earthquakes, including the Aceh earthquake on December 26, 2004 with 9.3 SR. In July and August 2018, earthquakes with a magnitude of $6.2 \mathrm{SR}$ and $7.0 \mathrm{SR}$ respectively occurred in Lombok. According to the data from the National Disaster Management Agency (BNPB), 83,392 building units are damaged. Distribution of 83,392 damaged buildings were found in North Lombok Regency 23,098 units (verified 12,493 units), West Lombok 37,285 units $(11,787$ units), East Lombok 7,280 units (3,121 units), Central Lombok 4,629 units (3,246 units), Mataram City 2,060 units (11,787 units) 1,482 units) and Sumbawa 9,040 units. Based on the visible data, a feasible system is developed to assist evaluators in categorizing building conditions rapidly and closely. The actual data are then reported through to the authorities the application after an earthquake disaster. In fact, the disaster management can be done precisely.

\section{Method}

Research and Development Method (Research and Development) is a research method used to produce certain products, and test the effectiveness of these products (Sugiyono, 2013: 297). The selection of this method is considered the most appropriate because before developing the realm of the information system or technology to be used, researchers must first make various initiations as guidelines for developing information systems. To support the development method, the researcher adopts an Analysis, Design, Development, Implementation and Evaluation (ADDIE) information system development model developed by Dick and Carry (1996). This development model is used as a guide in every step of the system development.

\section{Analysis}

The analysis phase is the initial stage carried out to gather various information related to data, facts, events or other references that can help researchers to do the system design needed. In-depth, thorough and clear analysis of the problems discussed will determine the accuracy of the algorithm which will affect the efficiency of the system and the ease of user (user Friendly) information systems developed. Another analysis needed is the choice of technology to be used as a core engine that supports multiple platforms on a user's device. Python as a core engine with Django framework, MySQL database and nginx as a webserver optimally supports the system. 


\section{Data Collection}

References The information used in this study is based on a report submitted by Stavros A. Anagnostopoulos, Marina Moretti, M. Panoutsopoulou, D. Panagiotopoulou, T. Thoma [5] from the European Commission - D.G. Environment Civil Protection - EPPO in a report entitled "Assessment of Damage and Feasibility of PostEarthquake Buildings: Further Development and Application". The report divides building inspection into two stages, namely rapid and detailed assessment. Rapid assessment is intended to identify buildings that are clearly not damaged so that they are safe and that are clearly not safe. Detailed assessment is intended to provide a final report on building safety. After a detailed assessment is carried out the evaluator will provide the building code in three color codes namely Safe to use (green) is the status of the building that has suffered minor damage and does not show signs of reduced seismic capacity. If there are local hazards, hazardous areas can be installed with barricades and access to buildings is blocked and marked "unsafe to use". Hazard Used (red) is the status of a building whose original seismic capacity drops dramatically and is therefore prone to sudden collapse even due to small aftershocks. Entry into the building is prohibited and the need for emergency support and surrounding protection must be considered. Unsafe to use (yellow) is the status of a building whose seismic capacity is reduced, although it does not have the danger of a sudden collapse and this building must be repaired before it can be inhabited continuously. Although some of these buildings may also require emergency support, there is a risk of entering them for a short time, for example to take valuables, secure the contents of an apartment etc. considered low (but should not be ignored). It must be remembered that buildings in this category have the greatest uncertainty in classification; if the inspector is doubtful about his evaluation, he must take a conservative attitude. Parameter of building damage based on:

\begin{tabular}{|c|c|}
\hline NO & Parameter \\
\hline 1 & $\begin{array}{l}\text { Building Structure Condition } \\
\text { Question } \\
\text { a) Intact } \\
\text { b) Partial } \\
\text { c) Total Collapse }\end{array}$ \\
\hline 2 & $\begin{array}{l}\text { Learning building is measured by a strand of } \\
\text { thread of } 100 \mathrm{~cm} \text { long) } \\
\text { Question } \\
\text { a) None/minor }(\mathrm{i}<0,75 \mathrm{~cm} / 100 \mathrm{~cm})) \\
\text { b) Medium }(0,75 \mathrm{~cm} / 100 \mathrm{~cm}<=\mathrm{i}<1,5 \\
\mathrm{cm} / 100 \mathrm{~cm}) \\
\text { c) Major }(\mathrm{i}>1,5 \mathrm{~cm} / 100 \mathrm{~cm})\end{array}$ \\
\hline 3 & $\begin{array}{l}\text { Building structure condition } \\
\text { Question } \\
\begin{array}{l}\text { a) None/minor }(\mathrm{d}<7,5 \mathrm{~cm}) \\
\text { b) Medium }(7.5 \mathrm{~cm}<\mathrm{d}<15 \mathrm{~cm})\end{array}\end{array}$ \\
\hline
\end{tabular}

\begin{tabular}{|c|c|}
\hline & c) Major $(\mathrm{d}>15 \mathrm{~cm})$ \\
\hline 4 & $\begin{array}{l}\text { Most severe column damages) } \\
\text { Question } \\
\text { a) None/minor }(\mathrm{d}<7,5 \mathrm{~cm}) \\
\text { b) Medium } \\
\text { c) Major }\end{array}$ \\
\hline 5 & $\begin{array}{l}\text { Most severe beam damages } \\
\text { Question } \\
\text { a) None/minor } \\
\text { b) Medium } \\
\text { c) Major }\end{array}$ \\
\hline 6 & $\begin{array}{l}\text { Most severe beam \& column joint damage } \\
\text { Question } \\
\text { a) None/minor } \\
\text { b) Medium } \\
\text { c) Major }\end{array}$ \\
\hline 7 & $\begin{array}{l}\text { Most severe shear wall damage } \\
\text { Question } \\
\text { a) None/minor } \\
\text { b) Medium } \\
\text { c) Major }\end{array}$ \\
\hline 8 & $\begin{array}{l}\text { Most severe bracing damages } \\
\text { Question } \\
\text { a) None/minor } \\
\text { b) Medium }\end{array}$ \\
\hline 9 & $\begin{array}{l}\text { Most severe floor plate damage } \\
\text { Question } \\
\text { a) None/minor } \\
\text { b) Medium } \\
\text { c) Major }\end{array}$ \\
\hline $\begin{array}{l}1 \\
0\end{array}$ & $\begin{array}{l}\text { Most severe stairs damage } \\
\text { Question } \\
\text { a) None/minor } \\
\text { b) Medium } \\
\text { c) Major }\end{array}$ \\
\hline $\begin{array}{l}1 \\
1\end{array}$ & $\begin{array}{l}\text { Wall or partition damage/crack } \\
\text { Question } \\
\text { a) None/minor } \\
\text { b) Medium } \\
\text { c) Major }\end{array}$ \\
\hline $\begin{array}{l}1 \\
2\end{array}$ & $\begin{array}{l}\text { Most severe damage on doors and windows } \\
\text { Question } \\
\text { a) None/minor } \\
\text { b) Medium } \\
\text { c) Major }\end{array}$ \\
\hline $\begin{array}{l}1 \\
3\end{array}$ & $\begin{array}{l}\text { Most severe ceiling damages } \\
\text { Question } \\
\text { a) None/minor } \\
\text { b) Medium } \\
\text { c) Major }\end{array}$ \\
\hline $\begin{array}{l}1 \\
4\end{array}$ & $\begin{array}{l}\text { Most severe roof damages } \\
\text { Question } \\
\text { a) None/minor } \\
\text { b) Medium } \\
\text { c) Major }\end{array}$ \\
\hline
\end{tabular}

Table. Parameter of building damage

Prototyping A System Of An Early Building Damage Assessment Effected By An Earthquake 


\section{Design}

To facilitate the development of information systems based on these parameters requires an algorithm, system architecture design and a precise and responsive core engine when running. The problem solving structure of the application built is as follows:

\section{- System Architecture}

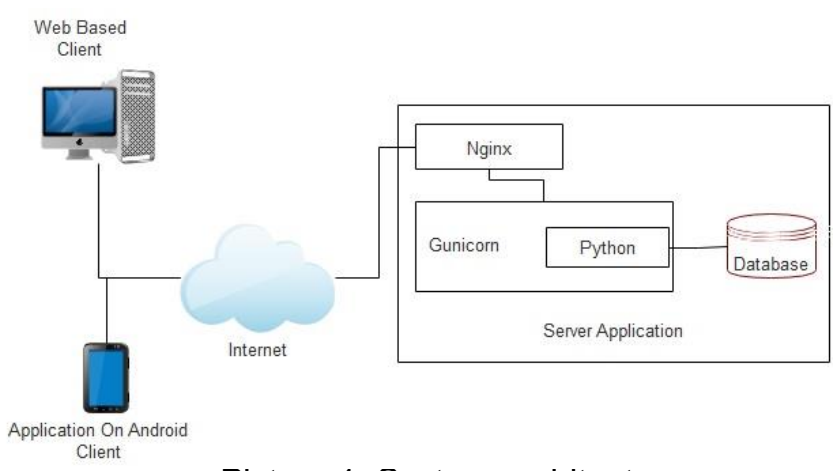

Picture 1. System architecture

Core engine system that will be developed using Python, so that making this application will be fast and good performance and easy to develop, this is seen from many large companies in the world such as Google using python as a core engine.

Because this is a web base application, Nginx is needed as a web server and is supported by Gunicorn for web server optimization so that it is faster and more efficient. This system will be installed on a cloud base server so that it is easy to access and maintain. So this application, if used simply open the browser and access the address of the application server.

Why is it web-based, so as not to limit the type of platform that can access the server, be it a desktop with any operating system, and mobile both Android and IOS so that under any circumstances in the field the application can still be utilized. With web-based technology now, it can be designed according to device size, so this application is responsive to device size.

\section{- Development}

Making an application begins with gathering information on the field technical team and collecting the types of forms that were originally used. The next step is to determine the role of each in the information system to assess the early damage to buildings affected by the earthquake. The mapping of actors involved in this information system is as follows.

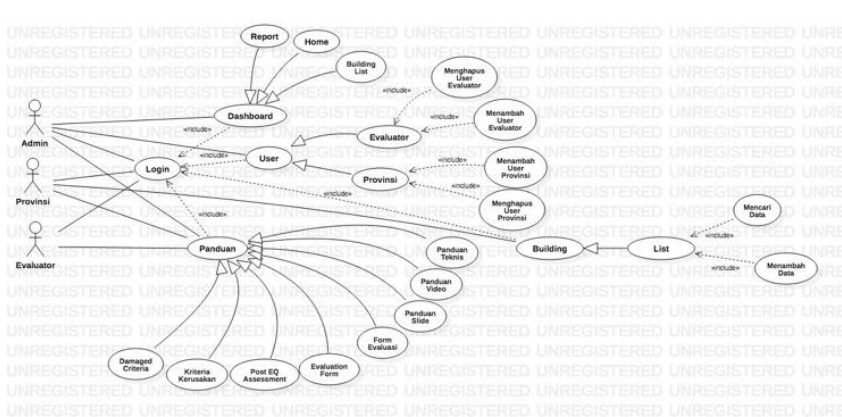

Picture 2. Use Case Dlagram

\section{Implementation}

The prototype system that has been developed until now is still in the form of an incomplete mockup system. However, it can display the location according to the coordinates and contained in the map.

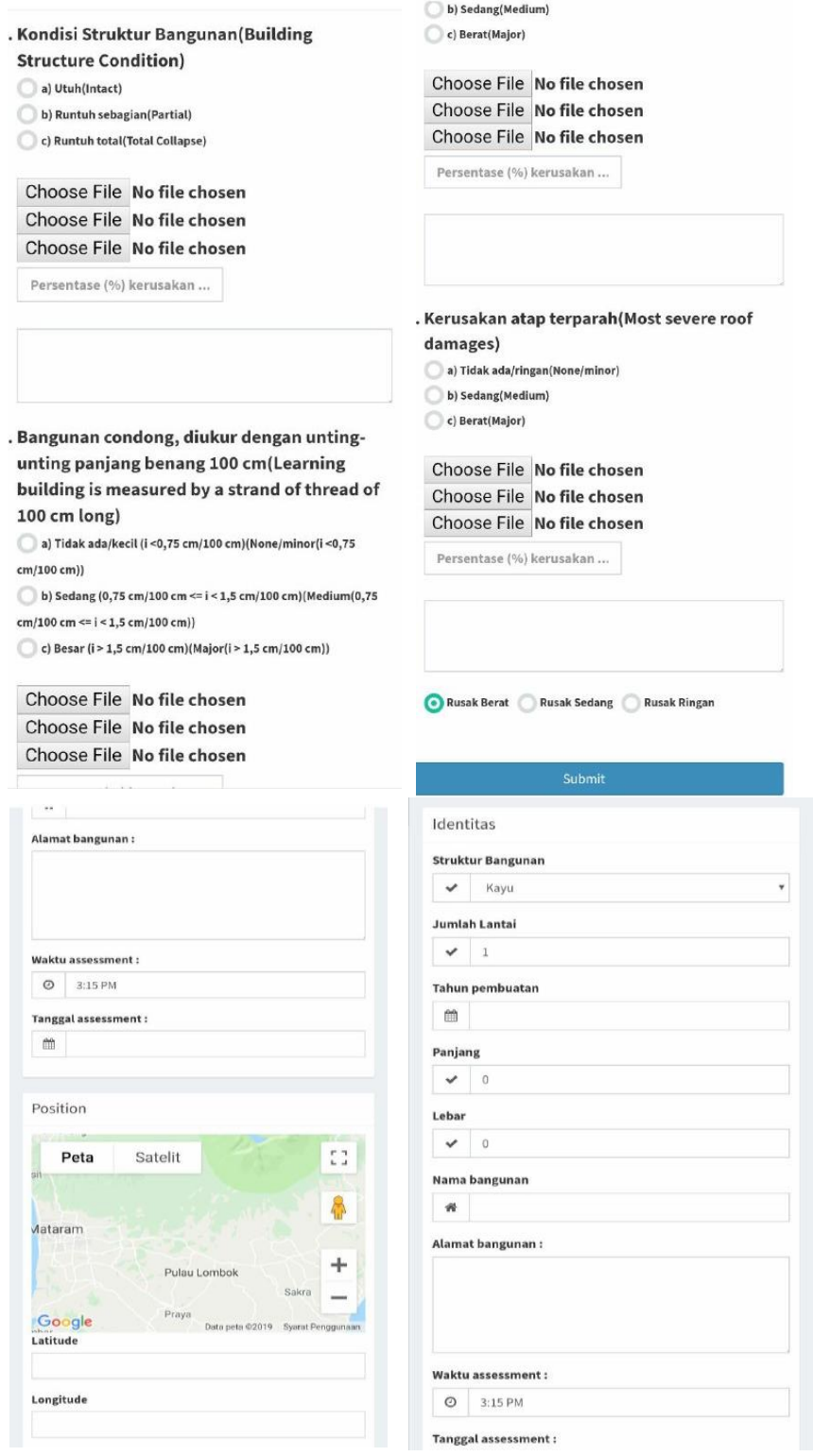

Picture 3. Form entry 


\section{-Evaluation}

The evaluation of the building damage assessment system for earthquake effects is carried out through a crosscheck of damage parameters set by the government. The format of the report will be assessed by the field evaluator team as backup data for other purposes

\section{Result}

The design of an early building damage assessment system by following the Analysis, Design, Development, Implementation and Evaluation (ADDIE) development model is still in the process of developing and is a prototype system, where the prototype is still at the limit of analyzing early building damage in the category of minor building damage. At the end of this study, a system will be developed to assess early damage to buildings caused by the effects of the earthquake. The output of the system will help field evaluators who have the qualifications to determine the early categories of damage in detail as material for making decisions quickly and can provide appropriate treatment.

\section{References:}

[1] Anita F. (2013), Panduan Praktis pemeriksaan Bangunan Akibat Gempa Bumi, Pusat Penelitian dan Pengembangan Permukiman PUPR.Bandung

[2] BMKG. 2019. http://repogempa.bmkg.go.id/

[3] BNPB. 2019 https://www.bnpb.go.id/32129-unitrumah-rusak-akibat-gempa-lombok-telah-diverifikasiupaya-perbaikan-rumah-terus-dilakukan,

[4] Sugiyono. (2013: 297), Metode Penelitian dan Pengembangan, Alfabeta. Bandung.

[5] Stavros A. Anagnostopoulos. (2012), Penilaian Kerusakan dan Kelayakan Bangunan PascaGempa: Pengembangan dan Aplikasi Lebih Lanjut, European Commission - D.G. Environment Civil Protection - EPPO.

[6] Kadir, Abdul, Pengenalan Sistem Informasi. ANDI

Offset. Yogyakarta. 